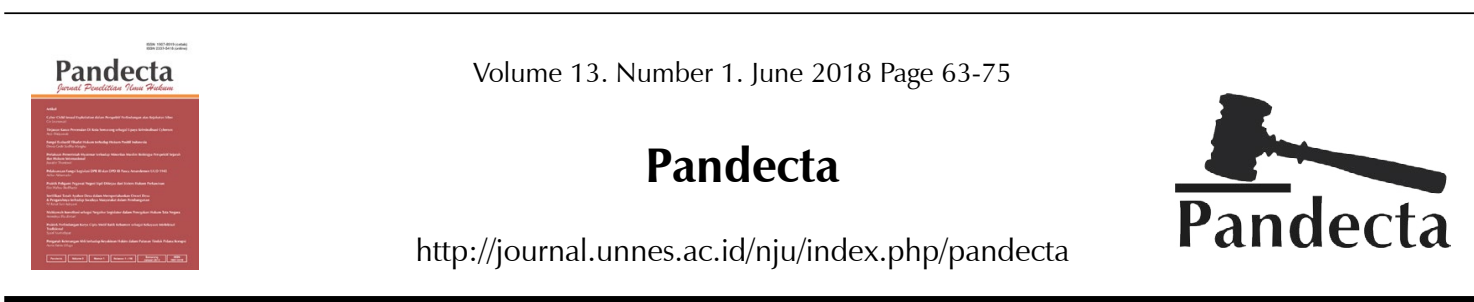

\title{
Rezim Hukum Khusus Atas Orbit Geostasioner (GSO) (Prospek dan Tantangan)
}

\author{
Anjar Supriadhie \\ Pusat Kajian Kebijakan Penerbangan dan Antariksa Lembaga Penerbangan dan Antariksa Nasional \\ DOI: http://dx.doi.org/10.15294/pandecta.v13i1.9220
}

\begin{abstract}
Article Info
Abstrak

Article History:

Received: March 2017;

Accepted: June 2018;

Published: June 2018

Pemanfaatan dan penggunaan GSO sampai dengan saat ini oleh negara berkembang khususnya negara-negara khatulistiwa dinilai masih menjadi masalah karena belum mencerminkan rasionalitas yang berkeadilan. Perjuangan oleh negara-negara berkembang termasuk didalamnya negara-negara khatulistiwa yang terus diupaya-

Keywords:

Sui generis regime;

GSO;

Challenges kan melalui UNCOPUOS (United Nations Committee on the Peaceful Uses of Outer Space) adalah agar ditetapkannya "suatu rezim hukum khusus". Tujuan penelitian ini adalah untuk mengetahui bagaimana prospek dan tantangan negara-negara dalam mewujudkan rezim hukum khusus. Penelitian ini adalah penelitian hukum normatif dengan menggunakan analisa pendekatan konsep dan peraturan perundang-undangan/konvensi serta teori sistim hukum. Hasil penelitian menunjukkan bahwa substansi isi rezim hukum khusus masih berupa usulan perspektif dari negara-negara berkembang termasuk didalamnya negara khatulistiwa yang menginginkan adanya pemberian hak lebih dan adil pada negara yang memiliki karakteristik khusus dan memiliki keterbatasan kemampuan dan sampai saat ini belum pernah ada negara yang mengusulkan wujud atau bentuk hukum internasional seperti apa yang akan diperuntukkan untuk pengaturannya. Berdasarkan hal ini, prospek negara-negara dalam perjuangan untuk mewujudkan adanya suatu rejim hukum khusus dalam forum UNCOPUOS dalam bentuk didasarkan pendekatan teori sistim (aspek kelembagaan hukum, substansi hukum maupun budaya hukum), sulit akan berhasil. Bentuk formil pengaturan internasional sebagai rejim hukum khusus GSO agar dapat memberikan kepastian hukum bagi negara-negara apabila dapat terbentuk adalah dalam bentuk atau berupa suatu hukum tertulis/ hard Law.
\end{abstract}

\begin{abstract}
Until today, the exploitation and use of GSO by developing countries especially equatorial states is still considered a problem because it does not reflect a just rationality. The effort by the developing countries including the equatorial states, which continue to be pursued through UNCOPUOS (United Nations Committee on the Peaceful Uses of Outer Space), is to enact the sui generis regime. The purpose of this research is to find out the prospects and challenges faced by the countries in pursuing such effort. This research is legal normative research by using conceptual approach analysis and statutory or convention as well as legal system theory. The result revealed that the substances of the sui generis regime is still a proposed perspective of developing countries, including the equatorial state that wants the granting of more and fairer rights in a country that has special characteristics and has limited capabilities, and until now there has never been a country that proposed a form or international legal form will be destined for its arrangement. The conclusion of this research is that the prospects of countries in the effort to enact a special legal regime in the UNCOPUOS forum in the form based on system theory approach (legal institutional aspects, legal substance and legal culture), is difficult to achieve. Formal form of international regulation as GSO's sui generis regime in order to provide legal certainty for countries if possible is in the form of Hard Law.
\end{abstract}




\section{Pendahuluan}

Sebagai upaya mempertahankan kelangsungan hidup berbangsa dan bernegara,adalah suatu kenyataan yang tidak dapat dipungkiri bahwa dalam pergaulan masyarakat internasional kedudukan negara berkembang dengan segala keterbatasan lebih fokus kepada upaya-upaya utuk mengatasi kemiskinan mencari terobosan dan peluang lapangan kerja bagi warga negaranya. Sebaliknya negara maju dengan dukungan kemampuan penguasaan teknologi yang luar biasa senantiasa tampil untuk selalu dapat melindungi kepentingan nasionalnya diberbagai kesempatan dan berbagai fora internasional. Kenyataan semacam ini adalah gambaran nyata yang terjadi dan berlangsung juga pada aspek pemanfaatan dan eksploitasi antariksa hingga dewasa ini. Dengan demikian negara-negara maju yang memiliki potensi dan kemampuan teknologi maju jelas memiliki kesempatan pertama untuk memanfaatkan sekaligus memperoleh keuntungan atas pemanfaatan dan ekploitasi antariksa tersebut.Sebaliknya negara berkembang dengan segala keterbatasannya selalu akan menjadi "follower"dan tertinggal.

Salah satu fakta aspek pemanfaatan dan eksploitasi antariksa yang memberikan cerminan adanya ketimpangan dan kesenjangan yang jauh antara negara maju dengan negara berkembang adalah pada aspek penggunaan dan pemanfaatanOrbitGeosta tioner(GSO).GSO sebagai wilayah strategis bagi penempatan satelit komunikasi, adalah suatu orbit yang berbentuk cincin yang terletak pada enam radian bumi diatas garis khatulistiwa, dimana satelit komunikasi harus ditempatkan dalam orbit tersebut agar berada pada posisi tetap sejalan dengan rotasi bumi (Sumardi, 2006: 103-104). Orbit ini mengitari bumi diatas garis khatulistiwa pada jarak ketinggian lebih kurang $36.000 \mathrm{~km}$.Secara alami satelit komunikasi tersebut akan stasioner pada orbit tersebut, oleh karenanya orbit ini disebut Geo Stationer Satelit Orbit (GSO). Pengaturan tentang GSO dilakukan oleh ITU (International Telecommunication Union) dan UNCOPUOS (United Nations Committee on The Peacefull Uses Of Outer Space), mendas- arkan pada Outer Space Treaty 1967, dansemuanya ada dalam Wadah dan di koordinasikan oleh Perseriktan Bangsa-Bangsa (PBB) (Abdurrasjid, 2008: 283).

Pemanfaatan dan penggunaan GSO sampai dengan saat ini oleh negara berkembang dinilai belum mencerminkan rasionalitas yang berkeadilan secara merata terhadap setiap negara anggota ITU/PBB( Abdurrasyid, P.1977). Negara berkembang dan utamanya negara-negara khatulistiwa terus berjuang menuntut adanya rasionalitas dan keadilan, sehingga kepentingan negara-negara berkembang pada umumnya dan negara-negara khatulistiwa pada khususnya pada saatnya dapat juga memanfaatkan dan menggunakan GSO tersebut untuk dapat menempatkan satelit komunikasi untuk mendukung kepentingan nasional negaranya.

Perjuangan yang terus diupayakan oleh negara-negara berkembang termasuk didalamnya negara-negara khatulistiwa adalah agar dapat ditetapkannya "suatu rezim hukum khusus" (Sui Generis Regime) terhadap GSO yang merupakan spesialisasi/kekhususan dari rezim hukum internasional yang telah ada atau telah mengatur sebelumnya (Bahar, 1998). Negara-negara berkembang dituntut harus mampu mengeksplor apa yang akan menjadi isi subtansi dalam rezim hukum tersebut, dan hal ini menjadi hal menarik untuk diketahui tantangan mewujudkannya.

Penelitian ini bertujuan untuk menganalisis bagaimana prospek dan tantangan negara-negara berkembang termasuk di dalamnya negara khatulistiwa dalam memperjuangkan untuk adanya pengaturan internasional rezim hukum khusus atas GSO.

\section{Metode Penelitian}

Peneltian ini adalah penelitian hukum yuridis normatif. Jenis data yang digunakan adalah bahan hukum primer yang bersumber pada konvensi PBB dan Ketententuan lain terkait GSO. Penelusuran data dilakukan dengan cara studi pustaka. Adapun pendekatan yang digunakan adalah pendekatan konvensi dan atau perundang-undangan danpendekatan konsep (Wignjosoebroto, 2002). Data diolah secara deskriptif-kuali- 
tatif untuk menjawab pertanyaan penelitian dengan menekankan analisis menggunakan kedua pendekatan tersebut dan teori tentang sistim hukum yang menegaskan bahwa suatu sistim hukum terbangun dari kuntruksi: Kelembagaan hukum (Legal Structure), Subtansi hukum (Legal Subtance) dan Legal Culture/ Budaya hukum (Friedman, 2009).

\section{Hasil Penelitian dan Pembahasan}

\section{Pengaturan Pemanfaatan dan Penggunaan GSO}

Pengaturan pemanfaatan dan penggunaan GSO sesuai dengan wujud bendanya dan sifat manfaat teknis dalam pemanfaatan dan penggunaannya "terwadahi" dalam dua rumpun hukum internasional yaitu rumpun hukum internasional dalam sistem United Nation Committe on The Pacefull Uses of Outer Space (UNCOPUOS) dan rumpun hukum internasional dalam sistem ITUInternational Tellecomunication Union/ITU (Mauna, 2010). Pengaturan GSO dalam dua sistem Organisasi dalam Koordinasi Perserikatan Bangsa-Bangsa (PBB) dimaksud dapat dilihat secara ringkas sebagai berikut:

\section{Pengaturan GSO dilihat dari Space Treaty 1967}

Pengaturan terhadap GSO ebagai wujud bendanya tidak diatur secara eksplisit dalam Space Treaty 1967 (Kantaatmaja, 1986). Karena letak GSO yang berada di wilayah antariks, maka pengaturannya berlaku ketentuan Space Treaty 1967, hal ini dapat diindikasikan dari melihat ketentuan artikel 1 sebagai berikut:

"Outer space, including the moon and other celestial bodies, shall be free for explotartion and use by all State, Without discrimination of any kind, on basis equality and in acorrdance whit international law...".

Dengan demikian setiap negara sesuai dengan ketentuan dalam treaty dapat memanfaatkannya secara adil tanpa diskriminasi antara negara satu dengan negara lain. Selanjutnya ketentuan dari Artikel 2 yang menyatakan: Outer Space including the moon and other special bodies, is not subject to national appropriation by claim of sovereignty, by me- ans of uses occupation, or by other means. Antariksa termasuk bulan dan benda langit lainnya (termasuk didalamnya GSO), bukan merupakan subyek yang dapat dimiliki dengan suatu klaim/tuntutan kedaulatan, dengan cara apapun termasuk penundukan, ataupun dengan cara-cara lainnya. Ketentuan ini menegaskan bahwa antariksa (di dalamnya GSO) adalah wilayah bersama kepentingan umat manusia yang tidak boleh dimiliki dan dikuasai dengan cara apapun oleh suatu negara. Pemanfaatan dan penggunaan antariksa (termasuk bulan dan benda langit lainnya,.. didalamnya termasuk GSO) dapat dilakukan oleh setiap negara dengan tujuan damai.Kentuan ini sebagiamana dinyatkan dalam arikel 4: ".... the moon and other celestial bodies shall be used by all State Parties to the Treaty exclusively for peacefull porposes..... "Bulan dan benda-benda langit lainnya (termasuk didalamnya GSO) (Sumardi, 2006) dapat dimanfaatkan oleh semua negara dengan tujuan damai.

Ketentuan pengaturan dalam Space Treaty 1967 terhadap GSO sebagai upaya perluasan makna pengertian "benda langit lainnya - and Part of Outer spacetermasuk didalamnya GSO" adalah kehendak negara-negara yang mengacu dan mendasarkan bahwa GSO adalah juga sebagai suatu benda langit yang berupa jalur Orbit adalah wilayah strategis bagi penempatan wahana antariksa dan sebagai sumber daya alam memliki sifat yang terbatas, dan oleh karenanya penggunaan dan pemanfaatannya perlu diakomodir dalam ketentuan internasional, dalam hal ini Space Treaty 1967, dalam hal ini sifatnya sangat normatif. karena sebagai perluasan penafsiran pada pengertian dan makna yang terkandung dari kata "celestial bodies-and Part of Outer space" (benda langit lainnya, termasuk didalamnya adalah GSO) dan belum diakui sebagai hukum internasional positip dan mengikat. Ketentuan dan pengaturan kepentingan terhadap GSO yang dituntut dapat dihasilkan oleh UNCOPUOS dalam suatu ketentuan diluar Spcace Treaty 1967 adalah pengaturan yang terkait dengan prosedur pamanfaatan lokasi, slot orbit di GSO dan penggunaan frequensi radio (Yasidi, 2007). 
Pengaturan GSO dilihat dari ketentuan ITU

Pengaturan aspek teknis penggunaan GSO dibahas dan dikeluarkan oleh ITU. Pengaturan GSO dilihat dari aspek sifat manfaat teknis sebagai sumber daya alam terbatas, diatur dalam artikel 33 ayat (2) dari ITU Convention tahun 1973 sebagai berikut:

"In using Frequensi band for souce radio servis shll bear in mind that radio frequensi and the Geostationary satellites orbit are limited natural resources, that they must be used efficienly and economically".

Ketentuan ini intinya menegaskan yang berkaitan bahwa GSO merupakan sumber daya alam terbatas, dan oleh karenanya harus digunakan secara eknomis dan efisien dan penggunaannya dilakukan secara equitable disesuaikan dengan kebutuhan fasilitas teknik yang dimiliki oleh negara-negara. Konsekuensi dari ketetentuan rumusan (b) ini, inilah yang memperkuat berlakunya prinsip First Come First served bagi GSO yang hanya menguntungkan kelompok negara yang memiliki dan menguasai kemampuan teknologi yang notabene adalah negara- negara maju karena hanya kelompok negara inilah yang dapat memanfaatkan dan menggunakan GSO secara "terkendali". Dalam pemanfaatan dan penggunaan terhadap GSO pada intinya terjadi perbedaan pandangan dan prinsip antara negara maju dengan negara berkembang khususnya negara-negara khatulistiwa, yang merasa perlu memperoleh perhatian dan hak yang adil atas GSO karena keistimewaan geografis dan alamiah yang dimilikinya dikaitkan dengan keberadaan jalur orbit GSO yang berbentuk cincin dan melingkar sejajar dengan khatulistiwa (Agus, 2011).

Pengaturan aspek teknis penggunaan GSO ini sejalan dengan kemujuan teknologi komunikasi dan kebutugan negara-negara, dengan maksud untuk mengakomodasikan kepentingannya selalu dilakukan pemutakhiran. Pemutakhiran dan penyesuaian dilakukan atas dasar dan memperhatikan hasil kesepakatan negara-negara dalam pembahasan yang berkatan dengan penggunaan frequensi orbit satelit yang dilangsungkan dalam sidang-sidang WARC (World Administrative Radio Conference) dan pembahasan yang berkaitan dengan masalah GSO dari sidangsidang yang berlangsung di UNCOPUOS. Pemutakhiran yang telah berlangsung secara singkat terlihat sebagai berikut ini (Supancana, 1994).

Pada Sidang ITU 1977 yang berlangsung di Jenewa, untuk pertama kalinya Deklarasi Bogota 1976 (sebagai wujud perjuangan negara-negara termasuk didalamnya negara khatulistiwa yang diperjuangkan dalam forum UNCOPUOS) disuarakan dalam sidang ini. Namun dalam sidang ini negaranegara khatulistiwa gagal memperjuangkan memasukan agenda pembahasannya dalam agenda sidang ITU ini. Putusan sidang menetapkan bahwa UNCOPUOS lah yang dianggap tepat untuk membahasnya (Suherman, 2000). Selanjutnya pada pertemuan Naerobi (Kenya)1982, tuntutan negara-negara khatulistiwa dan hasil UNISPACE 1982 sebagai hasil pembahasan dalam UNCOPUOS telah dapat mempengaruhi rumusan pemutakhiran ketentuan ITU, indikasi pengaruh tersebut dalam hal ini dapat terlihat dalam perubahan ketentuan artikel 33 ayat(2) yang menjadi berbunyi sebagai berikut:

"all countries have equal acces for space radio
communication services and position in the
CSO" sebelumnya berbunyi: In using Frequen-
si band for souce radio servis shall bear in mind
that radio frequensi and the Ceostationary sa-
tellites orbit are limited natural resources, that
they must be used efficienly and economical-
ly".

Dengan rumusan baru ini, semua negara oleh ITU, mendapatkan kesempatan akses secara adil atas pemanfaatan frequensi radiodan GSO. Perkembangan selanjutnya pada pertemuan WARC tahun 1985, sebagai upaya yang memungkinkan setiap negara memperoleh kesempatan yang sama dalam pemanfaatan GSO tanpa memandang tingkat perkembangan kemampuan ekonomi maupun ilmu pengetahuan diajukan dan dibahaslah dalam sidang ini suatu prinsip penggunaan GSO yaitu: Prinsip apriori planning.Dalam perkembangan pembahasan dan penetpan rencana apriori planning ini ternyata membawa implikasi yang luas, terutama terhadap tuntutan yang diajukan oleh negara khatulistiwa yang menegaskan bahwa dengan 
prinsip apriori planning ini negara khatulistiwa sebagai negara yang secara geografis dan secara alamiah punya keistimewaan prinsip ini dinilai akan dapat merugikan kedudukan dan kepentingannya sebagai negara- negara yang memiliki keistimewaan khusus terhadap GSO dibanding dengan negara- negara lain diluar khatulistiwa. Dalam perkembangan selanjutnya beberapa ketentuan penting yang mengatur GSO dituangkan dalam Konstitusi ITU 1994 dan Radio Regulation sebagai berikut:

\section{Konstitusi ITU 1994, Kyoto}

Dalam artikel 19 (butir 11 a) dan Pasal 44 Nomor 196 Paragraf 2 Konstitusi ITU, kyoto yang menyatakan bahwa: Spektrum frekuensi radio dan GSO adalah sumber daya alam terbatas dan harus digunakan secara rasional, efisien dan ekonomis, agar negara atau kelompok negara mempunyai persamaan akses terhadap sumber alam terbatas tersebut, dengan mempertimbangkan kebutuhan khusus negara-negara berkembang dan situasi geografis negara tertentu.

\section{Radio Regulation}

Edisi tahun 1993 artikel 11, 12,13 dan 14 yang mengatur mengenai prosedur koordinasi penentuan penggunaan sepektrum frekuensi termasuk slot orbit GSO. Maksud ITU membuat pengaturan tersebut adalah untuk dapat mengakomodasikan kepentingan semua negara yang mempunyai jangkauan jauh kedepan. Namun dalam kenyataannya adanya ketentuan tersebut telah menimbulkan masalah baru, antara lain munculnya pengajuan "papers satellites" oleh berbagai negara, yaitu pengajuan pengajuan slot-slot orbit tertentu untuk satelit-satelit yang belum jelas rencana dan waktu peluncurannya. Adanya papers satellites tersebut oleh negara-negara dipandang akan dapat mengurangi optimalisasi pemanfaatan GSO dan menutup peluang negara lainnya.

Perkembangan selanjutnya dengan adanya permasalahan paper satellites dan tuntutan negara-negara kemudian sejak 22 juni 1977 ITU memberlakukan syarat administratif yang disebut "Administrative Due Diligence" yaitu: Persyaratan administratif dalam penggunaan spektrum frequensi dan orbit satelit yang berupa kewajiban pemberian laporan oleh negara-negara pada Biro ITU yang berisikan informasi antara lain tentang negera yang meluncurkan, operator, kontrak dengan pembuat satelit, kontrak dengan wahana peluncur dan lain-lain (Michael, 1986).

Pada hasil sidang WARC 1998 dengan memperhatikan tuntutan negara dan perkembangan yang berlangsung ITU memetapkan prinsip Allotment Plan yang berisi pengalokasian jalur spektrum frequensi tertentu untuk Fixed Satellite Services (FSS) dan rejim pengaturan terhadap Unplaned Bandsyang maknanya dapat dikatakan tidak lagi mengedepankan ketentuan first come first served. Melalui penerapan prinsip allotment planini pada dasarnya semua negara berhak untuk mendapatkan minimal satu slot orbit GSO, baik untuk kepentingan telekomunikasi maupun penyiaran. Adapun Unplaned Bands dimaksudkan untuk menampung jasa-jasa yang belum direncanakan dan ditempuh berdasarkan prosedur pengajuan fequensi yang disebut frequency assignment sesuai dengan Artikel 11,12,13 dan 14 Radio Regulation yaitu melalui tiga tahapan: (1) advance publication; (2) coordination and, (3) notification and recording in MIFR (Master International Register).

Perkembangan pengaturan penggunaan spektrum radio di ITU sampai dengan saat ini mendasarkan pada konstitusi ITU dan Radio Regulation yang berlaku sebagai hukum internasional positif (Mauna, 2010). Berdasarkan pada penjelasan masalah pengaturan GSO sebagaimana diuraikan dalam poin 1 dan 2 tersebut diatas, dilihat dari aspek kewenangan lembaga pembentuk pengaturan kepentingan penggunaan GSO,diketahui bahwa pembentukan pengaturan aspek politik dan hukum penggunaan GSO adalah menjadi wewenang UNCOPUOS, dan pembentukan dan pengaturan aspek teknis GSO adalah menjadi wewenang ITU.

\section{Wujud dan Subtansi Isi Rezim Hukum Khusus Pandangan/Usulan/Perspektif Negara-Negara}

Tuntutan adanya pengaturan khusus terhadap GSO sampai dengan saat ini te- 
rus diperjuangkan oleh negara berkembang termasuk didalamnya negara khatulistiwa. GSO tidak secara jelas diatur dalam Space Treaty 1967 karena ketentuan dalam Space Treaty sangat bersifat umum dan tidak dapat diterapkan terhadap situasi dan sifat unik yang dimiliki GSO dan aturan-aturan dalam ITU semata (Andhi, 2015). Permasalahannya terletak pada subtansi isi sui generis regim atas GSO, yaitu: apakah GSO bebas digunakan, atau berada dibawah kedaulatannegara khatulistiwa, atau diberlakukan hak preferensi bagi negara tertentu, atau status hukum lainnya. Dalam kaitan ini upaya perjuangan dan tuntutan negara-negara termasuk didalamnya negara khatulistiwa termasuk Indonesia terhadap perlu adanya pengaturan khusus terhadap GSO, dapat didiskripsikan secara umum sebagai berikut:

\section{Deklarasi Bogota 1976}

Deklarasi Bogota ditandatangani oleh perwakilan dari negara-negara khatulistiwa yaitu: Brasil, Kolombia, Ekuador, Kongo,Kenya, Indonesia dan Zaere pada Tahun 1976 di Bogota, dan oleh karenanya dikenal dengan Deklarasi Bogota Tahun 1976. Deklarasi ini pada dasarnya merupakan tuntutan dari negara-negara khatulistiwa yang berisi tuntutan kedaulatan terhadap jalur Orbit GSO yang berada diatas negara-negara khatulistiwa/tepat berada diatas wilayah kedaulatan mereka. Pengertian GSO dalam Deklarasi Bogota 1976 ini adalah sebagai berikut:

"The geostationer orbit is natural resource in the Equatorial plane in which the period of sidereal revolution of satellite is equal to the period of sidereal rotatian of the Earth and the satellite moves in the same direction as the earths rotation. When satellite describes this particular orbit, it is said to be geosstationary such a satellite appears to be geostationary in the sky when viewed from earth, and is fixed the zenith of given point on the equator whose longitutude is by definition that ofsatellite. This orbit is located at an approximates distance of 35,8877 km above the earths Equator". (Geostasioner orbit adalah orbit melingkar pada bidang Equatorial di mana masa sidereal satelit sama dengan pereode rotasi sidereal bumi dan bergerak satelit dalam arah yang yang sama dengan rotasi bumi. Ketika satelit menggambarkan orbit tertentu. Dapat dikatakan geostasioner satelit tersebut tampak geostasio- ner dilangit bila dilihat dari bumi dan tepat dititik puncak pada khatulistiwa sejajar dengan satelit. Orbit ini terletak pada jarak 35,877 km diatas bumi khatulistiwa).

Tuntutan negara-negara khatulistiwa ini bukanlah dimaksudkan sebagai tuntutan yang bersifat penguasaan terhadap wilayah (territorial claim), namun tuntutan tersebut lebih didasarkan oleh adanya fakta yang dipandang mereka sebagai ketidakadilan yang telah berlangsung dalam pemanfaatan GSO yang berdasar pada prinsip kebebasan untuk memanfaatkan bagi semua negara yakni first come first served. Sebagai dampak dari penerapan prinsip ini pemanfaatan GSO hanya didominasi oleh negara-negara maju karena mereka memiliki kemampuan untuk itu baik dari segi teknologi maupun finansial. Pemanfaatan GSO ini dalam kenyataannya telah menjadi suatu usaha komersialisasi oleh negara-negara maju tersebut, sehingga dirasasakan oleh negara-negera berkembang maupun negara khatulistiwa cenderung merugikan mereka maupun negara yang belum mampu untuk memanfaatkannya.

Deklarasi Bogota 1976 ini banyak mendapat reaksi yang luas dari negara-negara. Negara-negara maju menentang isi dan gagasan yang terkandung dalam deklarasi karena mereka berpandangan bahwa kandungan isinya bertententangan dengan kepentingan mereka dan tidak sejalan dengan ketentuan pada artikel 33 ayat (2) Konvnensi ITU: "In using Frequensi band for souce radio servis shall bear in mind that radio frequensi and the Geostationary satellites orbit are limited natural resources, that they must be used efficienly and economically"dan terutama bertententangan dengan artikel 2 Space treaty 1967: "Outer Space including the moon and other special bodies, is not subject to national appropriation by claim of sovereignty, by means of uses occupation, or by other means".

Poin-poin penting yang ditegaskan sebagai isi dalam Deklarasi ini adalah bahwa adanya kepentingan nyata (national interest) dari negara kolong, b) berada diatas wilayah sovereignty/kedaulatan negara mereka. Selanjutnya, GSO is a part of outer space which has a limited natural resource (GSO meru- 
pakan bagian dari antariksa sebagai sumber daya alam terbatas), dan memiliki interdependensi yang tinggi (higly Interdependence) dalam berbagai aspek dalam kepentingan pemanfaatannya (Supancana, 2008). Perkembangan perjuangan negara-negara khatulistiwa termasuk didalamnya Indonesia terhadap GSO yang dimulai dari deklarasi Bogota mendapatkan hal yang positif, sehingga pada sidang sub komite hukum tahun 1984 berhasil mengajukan Working Paper untuk dibahas (Doc No. A/AC.105/C.2/L.147) yang berisikan prinsip yang diusulkan untuk dipatuhi negara dalam pemanfaatan GSO. Prinsipprinsip yang merupakan subtansi ketentuan rezim khusus terhadap GSO ini adalah sebagai berikut:

1. Exclusively for peaceful purposes and the benefit of min kind;

2. Sui generis regime and rights of equatorial countries;

3. Oppotune and appropriate utilization;

4. Preferential rights;

5. Prior authorization;

6. International Co-operating and efficient;

7. Transfer of technology;

8. Removal of non-opertional or unutilized space object from the orbit.

Prinsip-prinsip tersebut menekankan suatu keinginan negara-negara khatulistiwa agar antariksa dapat dipergunakan dan dimanfaatkan semata-mata untuk kepentingan perdamaian dan kemanusiaan (Sumardi, 2006). Terkait hal itu, posisi beberapa negaranegara pencetus deklarasi Bogota pada perekembangan waktu berjalan terdapat pergeseran sikap. Pada tahun 1984, pada sidang sub komite hukum UNCOPUOS, 4 negara ekuator ex pendukung deklarasi Bogota yaitu: Kolombia, Equador, Kenya dan Indonesia bergeser dari tuntutan kedaulatan menjadi perlu adanya hak Preferensi (hak didahulukan) dalam pemanfaatan atas GSO kepada negara khatulistiwa (preferential rights). Perubahan tuntutan didasarkan pada pertimbangan bahwa tuntutan kedaulatan dipandang tidak rasional dan sulit dipertahankan untuk keberhasilannya.

Pada masa sidang UNCOPUS ke 28 di New York negara berkembang dan negara khatulistiwa menyampaikan kertas kertas kerja yang memuat 5 (lima) prinsip mengenai GSO yang menyatkan sebagai berikut:

a. GSO is a limited natural resource

b. The development of space science and technology applied in the utilization of GSO;

c. GSO should be used exclusively for peaceful purposes

d. GSO is an orbit which lies in the plane of Earths equator;

e. All States should be guaranteed in practice equitable acces to hte GSO

Pada perjalanan waktu selanjutnya pada tahun 1992, negara Kolumbia mulai meninggalkan kebersamaan perjuangan dengan negara khatulistiwa lainnya dan kemudian berjuang dan bersikap atas nama negara berkembang dengan tuntutan perjuangan yang berbeda dari yang sebelumnya.

\section{Usulan negara-negara Kelompok 77}

Forum lain yang dapat dicacat dalam kaitan dengan pembahasan GSO ini dalam forum internasional adalah pada saat berlangsungnya UNISPACE 1982 di Wina. Dalam konverensi tersebut secara khusus dibahas masalah implikasi penggunaan GSO dalam hal ini berkaitan dengan kebutuhan dan kemungkinan mengoptimumkan penggunaanya, dan guna menetapkan tindakantindakan yang harus dilakukan untuk mencapai tujuan tersebut. mPada kesempatan ini negara-negara khatulistiwa kembali mengusulkan pembentukan suatu rezim hukum khusus bagi GSO dengan mengedepankan kepentingan dasar bagi negara khatulistiwa yang merasa mempunyai special geographical situation. Dalam sidang ini negara-negara yang termasuk dalam kelompok 77 , berhasil memperjuangkan suatu deklarasi tentang GSO yang menegaskan:

a. Increasing members of satellite are being use of various porpuses by different countries.

b. Desirable that member states, whitin the ITU:

(1) Continue to evolve some criteria for the mosteqitable and efficient useage of GSO and the Radio 
frequency Spectrum.

(2) To develop planning methods/ arrangements that are based on the genuine needs both present and future.

(3) Such a planning method should take into account the spesific needs of the developing countries as wellas the spesicial geographical situation of particular countries.

\section{Usulan Kolombia}

Pada tahun 1993 Kolombia menggagas working paper dengan subtansi tuntutan terhadap GSO dan berisi subtansi sebagai rezim hukum khusus bahwa: Penggunaan GSO hendaknya dapat diterapkan secara adil dan merata dan rasional kepada semua negara yang membutuhkan. Pada sidang sub komite hukum tahun 1995. Working paper Kolombia yang diajukan pada sidang tahun 1993 masih menjadi dasar pembahasan. Kertas kerja ini tidak menyebut secara eksplisit kepentingan negara khatulistiwa, tetapi menekankan pada konsep akses secara adil terhadap GSO melalui penetapan preferensi bagi negara berkembang dan negara yang belum mempunyai akses terhadap GSO. Bagi negara yang belum mempunyai kemampuan teknologi apabila secara bersamaan meminta slot orbit yang sama, maka yang diberikan preferensi adalah pada negara yang telah memimiki kemampuan. Preferensi tersebut dilaksanakan tanpa mengabaikan peran ITU dalam aspek teknisnya. Sedangkan bagi sesama negara maju atau negara berkembang yang diterapkan adala prinsip first come first served. Dalam pembahasannya working paper Kolumbia dipandang masih belum memberikan kejelasan dan masih banyak menimbulkan pertanyaan antara lain mengenai definisi dari "negara berkembang" (developing countries), status GSO sebagai sumber alam terbatas, penggunaan kata-kata "specific preferential rights"atas GSO dikaitkan dengan fenomena komersial yang pada faktanya dewasa ini GSO tidak semata-mata digunakan oleh negara, tetapi oleh negara diserahkan kepada badan komersial.

Pada tahun 1996 Kolombia merefisi working paper tersebut dan disampaikan pada sidang ke 35 sub kumite hukum dalam dokumenDoc.A/Ac.105/C.2/L.200 and Corr.1. yang berisikan prinsip-prinsip untuk direkomendasikan dalam perumusan aturan penggunaan GSO (Abdurrasjid, 2008) sebagai berikut:

a. When the need arises for processes of co-ordination beetween countries, due to possible radio electronic interference in respect of bands and services not planned by ITU using geostationary satellite orbit must take place, inter alia, in an equitable manner and that, consequent a developing country have equal claims to acces to the same orbital position or neighboring position, or when a country which has already had acces to the goestationary or bit shall, in the co- ordination procedure, offer all possiblities for the other country to have such acces with the minimum of operational restrictions possible.

b. The claim of countries to use frequncies to occupygeostasionaryorbital positions in the cases provided for above shall be exercised under the conditions set forth in the ITU Radio Regulations and, in any event, account shall be taken of the provisions of Resolutions 18 of the 1994 Kyoto Conerence to guarantee affective use of the geostastionary orbit.

c. Best efforts shall be made by the satellite launching state to remove space debris and spent satellites orbit from the geostationarysatellite orbit to disposal orbits shortly before the end of useful lives of satellites, in order to ensure the affective and economical use of this orbit.

Rumusan tersebut memperlihatkan bahwa working paper Kolombia mengarah pada pengaturan mengenai preferensi bagi negara berkembang dan negara yang belum mempunyai akses atas GSO, yang dalam hal ini dikaitkan dengan pengaturan spekruk frekuensi dan pelayanan (service) yang tidak direncanakan oleh ITU. Disamping hal tersebut ditegaskan juga mengenai keharusan bagi negara maju atau negara yang telah punya akses untuk memberikan kepada negara berkembang untuk mendapatkan akses 
atas posisi orbit dan spektrum frekuensi yang dikehendakinya, atau mendapatkan akses dengan sekecil mungkin adanya pembatasan-pembatasan operasional. Selanjutnya ditegaskan juga bahwa untuk pemanfaatan spektrum frequensi dan penempatan posisi orbit di GSO tersebut akan diberlakukan persyaratan yang dimaksud dalam ITU Radio Regulations, dan ketentuanResolusi 18 Kyoto Converence, dengan tujuan untuk menjamin penggunaan GSO secara efektif dan ekonomis. Ditekankan juga kepada negara- negara peluncur untuk memindahkan space debris dan satelit dari ruas GSO ke orbit pembuangan (disposal orbit) sesaat sebelum berakhir masa operasionalnya.

Berdasarkan pada ketentuan-ketentuan mendasar tersebut, dipahami dan diketahui bahwa penekanan pengaturan dimaksudkan tidak lagi pengaturan untuk status hukum GSO, tetapi lebih kepada konsep pengaturan penggunaan spektrum frequensi dan kepentingan-kepentingan yang tidak direncanakan oleh ITU. Dengan demikian subtansi isi sui generis regime menurut working paper Kolumbia ini adalah sama dengan pengaturan ITU, yaitu mengatur spektrum frequensi dan bukan mengatur tentang status hukum "ruang" GSO sebagaimana yang selama ini dituntut dan diperjuangkan oleh negara-negara khatulistiwa termasuk didalamnya Kolombia sendiri. Perjuangan Kolumbia ini pada prinsipnya terlihat adanya kecenderungan bahwa pembahasan tentang GSO lebih tepat dilakukan pada ITU dan bukan di sidang UNCOPUOS.

Perdebatan panjang antara negara maju dengan negara berkembang dan negara khatulistiwa berlangsung keras, pada akhirnya pada sidang ke 35 ini disepakati agar sekretariat UNCOPUOS dan sekretariat ITU melakukan analisis kompatibilitas pendekatan yang dimuat dalam working paper Kolombia dengan ketentuan ITU tentang penggunaan GSO. Dan hasilnya dibahas pada sidang sub komite hukum ke 36 tahun 1997.

\section{Usulan Jerman}

Setelah adanya kesepakatan bahwa UNCOPUOSdan ITU untuk dapat melakukan analisis Kompatibilitas tentang penggu- naan GSO terhadap usulan working paper Kolumbia, pada berlangsungnya sidang Sub Kumite Hukum ke 36 tahun 1997, Jerman mengajukan working papers yang berjudul "draft Resolutions Request to the International Telecommunication Satellite Union: Ensuring Equitable Acces to the Geostationary Satellie Orbit" (Doc. A/AC.105/C.2/L.107). Isi working paper Jerman ini intinya adalah meminta agar anggota ITU membahas masalah menadasr tentang yang dimaksud dengan tentang equitable acces penggunaan GSO untuk semua negara atau kelompok negara dengan memperhatikan kepentingan negaranegara berkembang. Adapun diskripsi ringkasan isinya adalah sebagaiberikut:

a. Agar dilanjutkan usaha penyederhanaan prosedur koordinasi untuk penempatan Satelit di GSO;

b. Mengintensifkan upaya-upaya yang tidak memperkenankan munculnya berbagai notifikasi yang tidak perlu yang dapat menghambat equitable accces;

c. Mengintensifkan upaya untuk melindungi lingkungan GSO sesuai dengan rekomendasi ITU Resolutions 1003/1993, dan melakukan koordinasi dengan UNCOPUOS.

Negara-negara berkembangdan negara khatulistiwa tidak menerima usulan Jerman ini karena terlihat jelas bahwa Jerman dalam hal ini didukung negara Perancis, Kanada, Italia, Yunani dan Jepang cenderung akan membawa bahwa pembahasan hal-hal yang berkaitan dengan GSO hanya akan dibahas di ITU. Sementara negara-negara berkembang dan negara khatulistiwa tetap berpendangan bahwa pengaturan terhadap GSO menjadi kewenangan dari UNCOPUOS dan masalah GSO tetap menjadi salah satu mata agenda sidang dalam UNCOPUOS sedangkan ITU hanya mempunyai mandat menetapkan aturan aspek teknisnya. Usaha Jerman yang mendapat tantangan negara-negara berkembang dan khatulistiwa maupun kelompok 77 mengakibatkan pada akhirnya Jerman menarik kertas kerjanya untuk tidak dibahas lagi dalam sidang sub kumite hukum UNCOPUOS. 


\section{Posisi pembahasan GSO di UNCOPUOS sampai dengan saat ini}

Perkembangan pembahasan GSO samapai dengan saat ini, cenderung "statis" artinya belum ada kemajuan perkembangan yang signifikan dari pembahasan-pembahasan yang berlangsung khususnya yang berkaitan dengan tuntutan negara terhadap subtansi isi dalam sui generis regime terhadap GSO yang diperjuangkan negara-negara pada sidang- sidang sebelumnya. Sikap dan pandangan negara sampai dengan saat ini masih terbelah secara tajam antara negara maju dengan negara berkembang termasuk didalamnya negara khatulistiwa yaitu: Negara maju cenderung berupaya untuk tidak lagi membahas GSO pada agenda sidang di UNCOPUS, karena lembaga yang berwenang membahas masalah GSO adalah ITU dan negara berkembang termasuk didalamnya negara khatulistiwa, tetap menuntut bahwa GSO terus dibahas dalam sidang-sidang UNCOPUOS (sampai ada aturan sui generis regime penggunaan GSO), karena masalah politik dan hukum penggunaan GSO kewenangan pembahasannya ada pada UNCOPUOS dan bukan pada ITU.

Pembahasan masalah pengaturan penggunaan GSO sebagaimana diatas difokuskan pada subtansi yang khusus berkaitan dengan tuntutan negara untuk kepentingan pengaturan penggunaan GSO yang diperjuangkan perlu "diwadahi" dalam suatu rejim hukum khusus. Rejim hukum khusus yang dimaksudkan adalah suatu wujud ketentuan aturan yang khusus mengatur aspek politik penggunaan GSO diluar atau sebagai lex spesialis dari Space Treaty 1967 dan kewenangan pembentukannya ada pada UNCOPUOS dan juga merupakan lex spesialis dari ketentuan dari ITU yang memiliki kewenangan pembentukan pengaturan aspek teknis penggunaan GSO.

Dalam pembahasan-pembahasan yang berlangsung konsep hukum perspektif subtansi isi norma hukum dari rezim hukum khusus yang diusulkan oleh negara-negarasebagaimana dipaparkan diatas, kandungan isinya cukup jelas. Namun terhadap konsep bentuk atau wujud hukum khusus (rezim hu- kum khusus) seperti apa, apakah dalam bentuk suatu Convention, Treatyatau Agreement tidak ditemukan konsep dan belum pernah ada satupun negara yang mengusulkan konsepnya, yang ada adalah pembahasan yang menentukan kewenangan Lembaga pembentuk ketentuan/aturannya yang dalam hal ini menunjuk pada UNCOPUOS. Mendasarkan pada perspektif subtansi isi dalam rezim hukum khusus yang dibahas dalam sidang-sidang yang berlangsung, dapat dilihat kecenderungan dari wujud atau bentuk rezim hukum khusus tersebut termasuk dalam konsep hukum tertulis (hard law).

\section{Tantangan negara-negara dalam mewu- judkan Rejim Hukum Khusus atas GSO Pendekatan Teori Sistim Hukum}

Perjuangan dan upaya negara-negara berkembang maupun negara khatulistiwa untuk mewujudkan adanya suatu rejim hukum khusus penggunaan GSO sebagai suatu sumber daya alam terbatas, sehingga dikemudian hari dapat terjamin kebutuhan dan kepentingannya pada saat membutuhkannya sudah memakan waktu yang relatif panjang dan dihadapkan pada tantangan tidak saja keterbatasan kemampuan teknologi, kemampuan ekonomi maupun sumberdaya manusia, namun juga dihadapkan pada tantangan politik dan hukum dan tidak dapat diperkirakan kapan akan berakhirnya.

Sebagaimana telah diketahui bahwa aspek pembentukan aturan dan atau sistim hukum internasional untuk kepentingan penggunaan GSO kewenangannya ada pada dua kelembagaan internasional yang berada dalam sistim dan koordinasi Perserikatan Bangsa-Bangsa (PBB), dalam hal ini adalahuntuk aspek politik dan hukum ada pada UNCOPUOS dan untuk aspek teknis penggunaan GSO ada pada ITU. Tantangan aspek politik dan hukum seperti apa yang dihadapi negara-negara dalam upaya mewujudkan rezim hukum khusus untuk penggunaan GSO, dalam naskah ini didekati dan coba didiskripsikan dengan menggunakan pendekatan dan teori sistim hukum (Legal system theori). Teori sistim hukum adalah suatu teori yang menegaskan bahwa suatu tatanan aturan hukum 
akan dapat terbangun dan eksis sebagaisuatu sistim hukum apabila 3 (tiga) aspek sistim hukum (kelembagaan hukum, subtansi hukum dan budaya hukum) ada dan dapat bersinergi dengan baik (Friedman, 2009). Dengan mendasarkan pada 3 (tiga) komponen aspek sistim hukum teori sistim hukum, tantangan yang dihadapi negara-negara dalam mewujudkan suatu rezim hukum khusus terhadap penggunaan GSO,dalam koridor UNCOPUOS dapat dideskripsikan sebagai berikut:

\section{Aspek Kelembagaan hukum (Legal Structu- re)}

Keberadaan dan eksistensi serta peran UNCOPUOS sebagai organ yang dikoordinasikan PBB dan memiliki tugas dan wewenang pembentukan hukum keantariksaan internasional, UNCOPUOS telah eksis dan telah dapat melahirkan 5 (lima treaty keantariksaan) dan beberapa Resolusi beberapa aspek keantariksaan seperti Resolusi tentang Remote Sensing, Nuclear Power Sourches dan lainnya.

Selanjutnya, sistim kerja UNCOPUOS dalam mengambil keputusan hasil sidangsidang diterapkan sistim kesepakatan mutlak semua negara. Sistim kerja ini yang menjadikan akan tidak mudah suatu isu atau masalah yang dibahas dalam sidang-sidang akan segera dapat ditetapkan dan untuk selanjutnya diusulkan kepada Majelis umum PBB untuk menjadi suatu Resolusi. Kemudian, peningkatan suatu resolusi untuk kepentingan menjadi adanya suatu Treaty/Agrement memerlukan wajib mengikuti prosedur yang berlaku dan memakan waktu yang relatif lama.

Berdasarkan pada aspek kelembagaan dan mekanisme kerja yang diterapkan atau berlaku di UNCOPUOS, meskipun telah lama eksis dan telah menghasilkan treaties keantariksaan dan resolusi aspek keantariksaan lain, aspek kelembagaan terkait dengan sistim pengambilan keputusan, ditinjau dari pendekatan teori sistim hukum (aspek kelembagaan hukum )dapat diduga akan menjadi tantangan yang tidak mudah bagi kepentingan upaya mewujudkan rezim hukum khusus pada UNCOPUOS dan bahkan akan dapat menjadi faktor frustasi negara-negara yang memperjuangkannya.

\section{Aspek Subtansi hukum (Legal Subtance)}

Bentuk/wujud hukum sui generis regime terhadap penggunaan GSO belum pernah ada satupun negara yang mengusulkan, artinya dari sekian lama pembahasan GSO yang berlangsung di sidang-sidang UNCOPUOS belum pernah dibahas. Apabila ada usulan yang disampaikan oleh negara, dapat dipastikan akan terjadi perdebatan dan waktu yang lama pada pembahasannya. Adapun usulan rumusan perspektif subtansi isi rezim hukum khusus yang disampaikan negara-negara (negara berkembang, negara kelompok 77, negara khatulistiwa) dikaitkan dengan kepentingan dan posisi negara maju akan sulit mendapatkan persetujuan, karena negara maju memiliki pandangan dan sikap bahwa masalah penggunaan GSO, yang memiliki kompetensi dan kewenangan secara internasional adalah ITU.

Secara faktual, belum pernah ada usulan tentang bentuk/wujud hukum yang dimaksudkan sebagai wadah dari rezim hukum khusus penggunaan GSO dan fakta masih tegasnya perbedaan pandangan antara negara maju dengan negara berkembang terhadap posisi dan penggunaan GSO dan negara maju berpandangan bahwa hanya ITU yang memliki kewenangan unutuk hal tersebut, dari pendekatan subtansi hukum, fakta ini akan menjadi tantangan yang relatif sulit dan berat untuk dapat memperjuangkan lebih jauh untuk adanya rezim hukum khusus terhadap penggunaan GSO dan terbentuk atau terlahir dalam koridor kewenangan UNCOPUOS.

\section{Aspek Budaya Hukum (Legal Culture)}

Sejarah dan eksistensi dan peran UNCOPUOS dan ITU telah menjadi hal yang given dan dipandang serta dirasakan tidak menjadi masalah bagi negara-negara. Sementara itu, proses pembentukan hard law melalui UNCOPUOS terhadap GSO yang memakan waktu lama dipandang hanya membuang waktu, kesempatan dan energi yang sia-sia. Kemudian, berdasarkan hukum keberadaan dan perangkat aturan yang telah ada pada ITUsebagai acuan dalam penggunaan GSO telah melekat sebagai budaya hukum negara-negara dan selama ini dalam pelaksanaannya dirasa tidak menimbulkan 
persoalan berarti oleh negara-negara.

Persoalan budaya hukum sebagaimana tersebut diatas, menunjukkan bahwa fakta dan kondisi seperti ini, merupakan tantangan yang menjadikan semakin sulitnya negaranegara untuk dapat meujudkan adanya rezim hukum khusus atas penggunaan GSO sesuai dengan kepentingan dan kedudukan masingmasing negara yang memperjuangkan.

\section{Simpulan}

Berdasarkan pemaparan dan pembahasan sebagaimana tertuang dalam Bab dan poin-poin sebelumnya, dapat ditarik kesimpulan bahwa belum ada satupun negara yang mengusulkan wujud pengaturan internasional formal yang dipandang tepat untuk mewadahi pengaturan untuk rezim khusus bagi GSO. Perspektif rumusan usulan subtansi isi rezim hukum khusus terhadap penggunaan GSO yang diusulkan beberapa negara terdapat kecenderungan mengarah pada bentuk tertulis atau dalam wujud hard law sebagai berikut:

1) Perspektif rumusan subtansi isi rezim khusus usulan negara berkembang, negara khatulistiwa maupun negara lainnya intinya memiliki tuntutan yang relatif sama bahwa pengaturan penggunaan GSO menjadi wewenang UNCOPUOS dan penggunaan GSO dapat diterapkan secara adil dan memperhatikan kepentingan negaranegara khususnya negara yang memiliki karateristik alamiah yang unik dengan GSO, untuk alokasi penggunaan spektrum frequensi dilakukan secara adil mendasarkan pada ketentuan ITU.

2) Didasarkan pada 3 komponen aspek dalam teori sistim hukum, upaya mewujudkan rezim hukum khusus dalam Wujud/bentuk hukum tertentu, dihadapkanpada tantangan yang sangat sulit dan cenderung tidak mungkin akan dapat terwujud.

Beberapa tantangan yang ada antara lain adalah bahwa sistim kerja UNCOPUOS dalam mengambil keputusan hasil sidangsidang diterapkan sistim kesepakatan mutlak semua negara. Sistim kerja ini yang menjadi- kan akan tidak mudah suatu isu atau masalah yang dibahas dalam sidang-sidang akan segera dapat ditetapkan dan untuk selanjutnya diusulkan kepada Majelis umum PBB untuk menjadi suatu Resolusi. Selain itu, bentuk / wujud hukum sui generis regime terhadap penggunaan GSO belum pernah ada satupun negara yang mengusulkan, artinya dari sekian lama pembahasan GSO yang berlangsung di sidang-sidang UNCOPUOS belum pernah dibahas. Apabila ada usulan yang disampaikan oleh negara, dapat dipastikan akan terjadi perdebatan dan waktu yang lama pada pembahasannya. Selanjutnya, fakta hukum keberadaan dan perangkat aturan yang telah ada pada ITU sebagai acuan dalam penggunaan GSO telah melekat sebagai budaya hukum negara-negara dan selama ini dalam pelaksanaannya dirasa tidak menimbulkan persoalan berarti oleh negara-negara.

\section{Daftar Pustaka}

Abdurrasyid, P. 1977. Pengantar Hukum Ruang Angkasa "Space Treaty 1967". Bandung: Bina Cipta.

Abdurrasyid, P. 2008. Beberapa Bentuk Hukum Sebagai pengantar Menuju Indonesia Emas 2020. Fikahati bekerjasama dengan Badan Arbitrase Nasional Indonesia. Jakarta.

Agus, P. 2011. Orbit Geostasioner (GSO) dalam Hukum Internasional dan Kepentingan Nasional Indonesia, Jurnal Pandecta, Volume 6 Nomor 2, Juli 2011. Semarang: Unes.

Andhi, Adini T. 2015. Analisis Dampak Komersialisasi GSO ditinjau dari Aspek Hukum Ruang Angkasa. Skripsi FH UNHAS. Makasar.

Bahar,W.1998. Pertanggungjawaban Negara Terhadap AktifitasKomersial di Ruang Angkasa dan Perkembangannya. Editor. E Saefullah Wiradipraja dan Mieke Komar Kantaatmaja. Bandung: Remaja Karya CV.

E, Suherman, E. 2000. Aneka Masalah Hukum Kedirgantaraan (Himpunan Makalah). Bandung: Mandar Maju.

Friedman, Lawrence W. 2009. Sistem Hukum, Perspektif Ilmu Sosial. terjemahan M. Khosim, Bandung: Nusa Media.

Kantaatmaja, MK. 1986. Berbagai Masalah Hukum Udara dan Angkasa, Bandung: Remaja Karya.

Mauna, B. 2010. Hukum Internasional, Pengertian, Peranan dan Fungsi Dalam Era Dinamika Global, Bandung: Alumni.

Michael J.1986. Limited Space: Allocating the Geostationary Orbit, Northwestern Journal of International Law and Business, Vol 7, issue 4.

Sumardi, J. 2006. Hukum Ruang Angkasa (Suatu Pengantar). Jakarta: PT Pradya Paramita.

Supancana, IBR. 1994. Aspek Regulasi Dalam Pemanfaatan Orbit Khususnya Orbit Geostationer 
dan kaitannya dengan Kepentingan Indonesia. Dalam Seminar FH Unpad Bandung.

Supancana, IBR. 2008. Perkembangan Pengaturan GSO dalam Forum Internasional dalam E. Saefullah dan Mieke Komar Kantaatmadja, Hukum Angkasa dan Perkembangannya. Bandung: Remaja Karya.

Wignjosoebroto, Soetandyo. 2002.Hukum, Paradigma, Metode, dan Dinamika Masalahnya. Jakarta: Elsam.
Yasidi, Hambali. 2007. Hukum dan Politik Kedirgantaraan. Jakarta: Pradya Paramita ( edisi baru).

Undang-undang Nomor 16 Tahun 2002 Tentang Pengesahan Treaty on Principle Governing the activities of States in The Exploration and Use of Outer Space Including The Moon and Other Celestial Bodies, 1967 (Traktat Mengenai Prinsip-Prinsip yang Mengatur Kegiatan Negara-negara dalam Eksplorasi dan Penggunaan Antariksa, Termasuk Bulan dan Benda- Benda Langit Lainnya, 1967). 